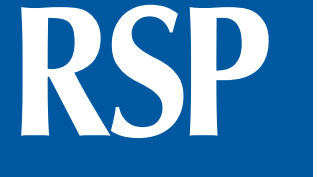

http://www.rsp.fsp.usp.br/
Revista de Saúde Pública

\title{
Challenges of health services related to the population displaced by violence in Mexico
}

María Beatriz Duarte-Gómez', Silvia Magali Cuadra-Hernández', Myriam Ruiz-Rodríguez", Armando Arredondo', Jesús David Cortés-Gil"'I

I Instituto Nacional de Salud Pública. Centro de Investigación en Sistemas de Salud. Cuernavaca, Morelos, México

" Universidad Industrial de Santander. Escuela de Medicina. Departamento de Salud Pública. Bucaramanga, Santander, Colombia

II' Universidade Federal de Pelotas. Programa de Pós-Graduação em Epidemiologia. Pelotas, RS, Brasil

\section{ABSTRACT}

OBJECTIVE: To analyze the impacts of the care to the population displaced by violence on the health system and the challenges that this entails.

METHODS: This is a narrative review of the national and international literature in PubMed, SciELO, WHO/PAHO, and Bireme. Inclusion criteria were date of publication ( from 2000), relation with the subject, and language (Spanish or English). We found 292 documents, of which 91 met the inclusion criteria.

RESULTS: The main challenges are the intersectoral, participatory, and integral approach (with emphasis on mental health and sexual and reproductive health), ensured accessibility to health services, the need for a reliable registration and information system of the population displaced by violence and its characteristics, and the addressing of the biopsychosocial problems of the different groups, especially women, persons with disabilities or infectious diseases, adolescents, children, ethnic minorities, older adults and the lesbian, gay, bisexual, transsexual, and intersexual population.

CONCLUSIONS: The lack of political will to accept and see the internal displacement by violence and its importance as a humanitarian and public health problem is an obstacle to the adequate and timely care of the population displaced by violence in Mexico.

DESCRIPTORS: Transients and Migrants. Minority Groups. Violence, prevention \& control. Exposure to Violence. Social Vulnerability. Health Vulnerability. Social Inequity, policies. Review.

Received: Jun 17, 2017

Approved: Aug 17, 2017

How to cite: Duarte-Gómez

MB, Cuadra-Hernández SM

Ruiz-Rodríguez M, Arredondo A,

Cortés-Gil JD. Challenges of health

services related to the population

displaced by violence in Mexico.

Rev Saude Publica. 2018;52:77.

Copyright: This is an open-access article distributed under the terms of the Creative Commons Attribution License, which permits unrestricted use, distribution, and reproduction in any medium, provided that the original author and source are credited. 


\section{INTRODUCTION}

A displaced population is defined as "individuals or groups of people who have been forced to flee their homes to escape armed conflict, generalized violence, and human rights abuses"'. It includes refugees - persons who crossed an international border - and internally displaced persons. This displacement becomes a public health problem ${ }^{2,3}$ and a challenge for the provision of health services (HS) in both the sending and receiving areas, many of which do not have the resources to respond to a sudden and massive influx of persons $\mathrm{s}^{4-6}$.

A displaced population faces a forced and abrupt transition that involves individual and family changes, both in their roles or relationships and in their material living conditions. This usually means shortages of resources, family conflicts, health risk behaviors, sexual abuse, physical and mental health problems, and human rights violations ${ }^{7}$. Displaced populations mainly have low and very low socioeconomic status (SES), which does not mean that persons with high SES are not displaced or do not suffer when they do so, but they can rely on greater cultural and economic capitals to face it ${ }^{8}$. Quality of life tends to worsen with displacement, especially in the transition phase - between choosing a temporary settlement until they can be permanently placed ${ }^{9}$. At this stage, there is no more emergency aid, and thus the economic situation often deteriorates ${ }^{10,11}$. The arrival of a new population affects the receiving area in relation to the labor market, security, and demand for public services. This sometimes leads to rejection and discrimination and the need to mobilize new resources at the state and city level ${ }^{3,12,13}$.

Official statistics on forced displacement are scarce and incomplete in Mexico. The internally population displaced by violence has increased in the country, especially in states such as Chihuahua, Michoacán, Sinaloa, Durango, and Guerrero ${ }^{3,14}$. In Mexico, 19,747,511 persons migrated internally in 2010, according to the 2015 data of the National Institute of Statistics and Geography (INEGI) ${ }^{15}$. The most frequent reasons were poverty, violence, and natural disasters $^{16}$. According to the 2014 National Demographic Dynamics Survey, six out of 100 migrants moved to another state motivated by public insecurity or violence ${ }^{17}$. According to the latest National Survey of Victimization and Perception on Public Security (ENVIPE) in 2014, 1.6 million persons migrated internally because of violence ${ }^{18}$. The study of Chávez and Warnner ${ }^{19}$, in 2012, estimates that Mexico has half a million internal migrants, with differences according to education level (lower education level plus group and rural migration) and age (younger individuals migrate more), with little difference by sex. However, they do not differentiate the cause of migration; they only mention Chihuahua and Sonora as sending areas, with little immigration and problems of organized crime.

Mexico had high internal migration for economic reasons, mainly from the south to the north of the country. It is also a transit point for Central and South American migrants to the United States ${ }^{20}$. However, it has not officially recognized the existence of internal migration by violence as a priority problem. Consequently, it is little visible, there is no adequate information, and the responses to this phenomenon were fragmented and insufficient, as well as the policies and programs for this population ${ }^{21}$. The Government must ensure the right to health, in a holistic conception, that goes beyond the medical care of the disease. This reluctance to acknowledge the existence of displaced populations hinders the care provided to them ${ }^{22}$.

Given the exposed problem, the objective of the study was to analyze the impacts of the care to populations displaced by violence to the health system and the challenges that this entails.

\section{METHODS}

This first approach was based on the identification and analysis of the national and international literature, which contributes with information for the formulation of public 
policies that allow the preparation, allocation of resources, design, and implementation of national programs that respond to the needs of this vulnerable population.

We carried out a narrative review of the literature on forced migration associated with violence and the response of health systems in documents published from 1995 to 2016. We included studies with different methodologies, from any country. The searches in PubMed, SciELO, WHO/PAHO, and Bireme were performed under the following terms in English and Spanish:

- Health services and/or Health system and internal displacement by violence;

- Displaced population and health services;

- Forced displacement and health in Mexico.

Inclusion criteria were date of publication, relation with the subject, and language (Spanish or English). Each document was classified by document type, geographical context, and category in relation to the subject (Table).

We found 292 documents, of which 91 met the inclusion criteria. Most $(n=75)$ were from the Latin America, almost all from Colombia. Of the 11 documents from Mexico, two were directly related to health services ${ }^{23,24}$ (Figure).

\section{RESULTS}

\section{Forced Displacement and Health Services}

We found scarce specific literature on the effect of forced displacement on HS. The articles related to the subject have identified its potential negative impact on human resources, as well as the increase in the needs of drugs, inputs, and infrastructure in health services².

Table. Classification of information found in the 1995-2016 literature review on displaced population and health services.

\begin{tabular}{|c|c|c|}
\hline Criterion & Type & Articles (n) \\
\hline According to type of source & $\begin{array}{l}\text { - Scientific articles } \\
\text { - Technical reports from agencies and NGO and theses } \\
\text { - International Agencies UNHCR, IOM, NGO } \\
\text { - } \quad \text { National Agencies } \\
\text { - Mans, programs, legislation } \\
\text { Manuals, guides }\end{array}$ & $\begin{array}{l}47 \\
30\end{array}$ \\
\hline $\begin{array}{l}\text { According to } \\
\text { geographical context }\end{array}$ & $\begin{array}{ll}\text { - } & \text { Mexico } \\
\text { - } & \text { Latin America } \\
\text { - } & \text { Other }\end{array}$ & $\begin{array}{l}7 \\
51 \\
35\end{array}$ \\
\hline $\begin{array}{l}\text { According to components } \\
\text { of Health Systems }\end{array}$ & $\begin{array}{ll}\text { - } & \text { Human resources } \\
\text { - } & \text { Infrastructure/Equipment } \\
\text { - } & \text { Organization/Operation } \\
\text { - } & \text { Financing/Costs } \\
\text { - } & \text { Other }\end{array}$ & $\begin{array}{c}17 \\
9 \\
23 \\
16 \\
41\end{array}$ \\
\hline $\begin{array}{l}\text { According to relation with } \\
\text { the subject }\end{array}$ & $\begin{array}{l}\text { Directly related: those that explicitly talk about health } \\
\text { services for a displaced population } \\
\text { Indirectly related: those whose main subject is the } \\
\text { characteristics of this population and health needs, which } \\
\text { is indirectly related to the services that must be provided to } \\
\text { meet them } \\
\text { Unrelated: those whose main subject is not related either to } \\
\text { health services or to the needs of the displaced population }\end{array}$ & $\begin{array}{l}42 \\
51\end{array}$ \\
\hline
\end{tabular}




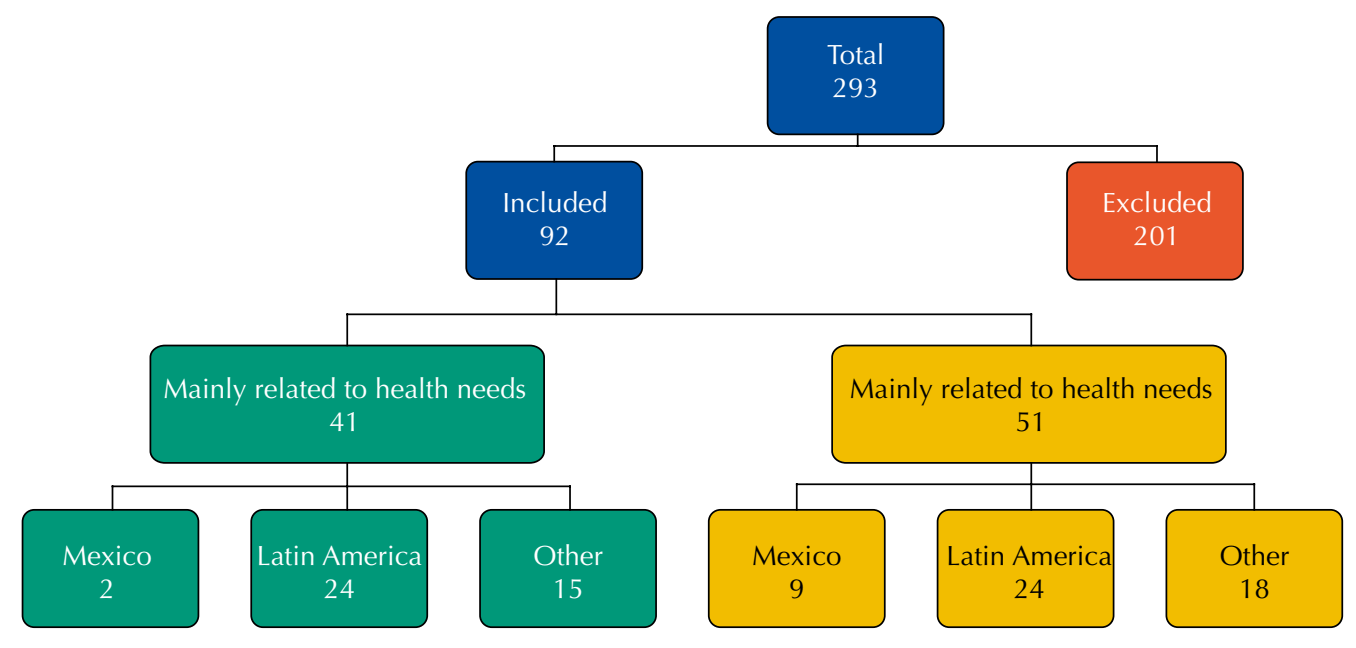

Figure. Number and type of documents selected in the 1995-2016 literature review on displaced population and health services.

A study on health and forced displacement in Sri Lanka, although focusing on post-conflict, has found three documents on HS. Most focused on the mental health problems of the displaced population ${ }^{25}$.

The article of the International Center for Migration and Health ${ }^{26}$ has highlighted the areas that should be the focus of health policies for this population: communication, infection control, maternal and child health, occupational health, violence, creation of health indicators, and staff preparation for the intercultural capabilities needed for the care of ethnic minority groups. Principle 19 of the "Guiding Principles on Internal Displacement" of the United Nations prioritizes the care of the displaced population with disabilities, infectious diseases, and women, especially in the field of sexual and reproductive health (SRH) ${ }^{1}$. The World Health Organization (WHO $)^{2}$ mentions that the public health should avoid inequities between the displaced population and the host population regarding the health condition and access to HS. To this end, it proposes that health rights should be ensured without discrimination and obstacles should be removed for preventive and curative interventions that reduce excess morbidity and mortality and minimize the consequences both on community health and cohesion.

Some studies have focused on barriers to access to services. The most mentioned ones were the geographic, economic, cultural, and bureaucratic barriers ${ }^{5,12,27-30}$. Some strategies used in Colombia to ensure access were the priority affiliation to social security or the portability of this affiliation, the flexibility to adapt to obstacles such as the frequent absence of identification document, and the care with mobile health brigades and managers ${ }^{29,31-33}$.

Others have mentioned the lack of staff training to handle social and health emergencies, aggravated by the high turnover from the work under stress conditions, lack of resources, and insecurity ${ }^{34}$. They also have highlighted local shortcomings in developing policies to support the displaced populations, whether for lack of interest, ability, incentives, or funding ${ }^{12,35}$. Most of the experiences came from Colombia, where a care model was designed for displaced populations, based on mobile teams focused on Primary Health Care (PHC) and specific manuals ${ }^{4,36}$.

There is a consensus about the characteristics that the HS should have for displaced populations, such as cultural acceptability ${ }^{2,5,26,37-39}$, integrality ${ }^{24,40}$, appropriate information system $^{4,41-43}$, being it intersectoral ${ }^{4,12,29,44-47}$, participatory ${ }^{5,29,33}$, and accessible ${ }^{24,27-31,37,43,48-51}$, and with security measures that ensure the lives of both the population and health personnel ${ }^{1,12,34,44,52}$ (Box 1). 
Box 1. Characteristics of the health services for population displaced by violence, found in the 1995-2016 literature review on displaced population and health services.

\begin{tabular}{|c|c|c|}
\hline Characteristic & Definition & Authors \\
\hline $\begin{array}{l}\text { Cultural } \\
\text { acceptability }\end{array}$ & $\begin{array}{l}\text { It implies adaptations in terms of } \\
\text { communication and organization when } \\
\text { the displaced population is indigenous } \\
\text { or comes from another region culturally } \\
\text { distinct from the receiving area }\end{array}$ & $\begin{array}{l}\text { Juliao-Vargas }{ }^{37} \text {, Lattay Goodman }{ }^{38}, \text { OMS }^{93} \text {, } \\
\text { Thomas y Thomas }{ }^{5}, \text { Kinzie }^{39}, \text { Siem }^{26}\end{array}$ \\
\hline Integrality & $\begin{array}{l}\text { To know how to identify and meet the } \\
\text { physical and psychosocial health needs, } \\
\text { which implies trained human resources }\end{array}$ & 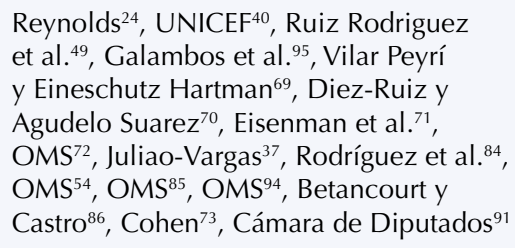 \\
\hline $\begin{array}{l}\text { With appropriate } \\
\text { information system }\end{array}$ & $\begin{array}{l}\text { To allow the differentiated care of the } \\
\text { population (according to sex, age, } \\
\text { ethnicity, health status) and the organized } \\
\text { allocation of resources }\end{array}$ & $\begin{array}{l}\text { Alcaraz López et al. }{ }^{41}, \text { IASC }^{42} \text {, Hernández } \\
\text { y Gutiérrez }{ }^{43}\end{array}$ \\
\hline $\begin{array}{l}\text { With intersectorial } \\
\text { coordination }\end{array}$ & $\begin{array}{l}\text { To meet basic needs (sanitation, housing, } \\
\text { food, education, security) }\end{array}$ & $\begin{array}{l}\text { Balladelli }{ }^{29} \text {, Bernal Pulido }{ }^{12}, \text { OPS }^{44} \text {, } \\
\text { Schuster y Schwendke }{ }^{45}, \text { Rodríguez } \\
\text { Neyra }^{4} \text {, Silva }{ }^{46} \text {, Fox et al. }{ }^{47}\end{array}$ \\
\hline Participatory & $\begin{array}{l}\text { To promote and enable the active } \\
\text { involvement of the population in the } \\
\text { decision-making of programs and strategies }\end{array}$ & $\begin{array}{l}\text { Balladelli }{ }^{29}, \mathrm{OPS}^{33}, \text { Ministerio de } \\
\text { Protección Social }{ }^{48}, \text { Thomas y Thomas }\end{array}$ \\
\hline Accessible & $\begin{array}{l}\text { With geographical, functional, economic, } \\
\text { and cultural access }\end{array}$ & 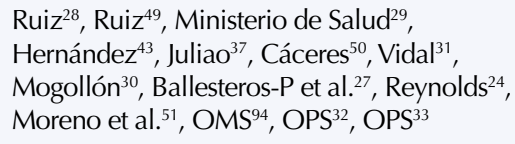 \\
\hline $\begin{array}{l}\text { With security } \\
\text { measures }\end{array}$ & $\begin{array}{l}\text { Both for displaced population and health } \\
\text { personnel }\end{array}$ & $\begin{array}{l}\text { Bernal Pulido }{ }^{12} \text {, Organización de las } \\
\text { Naciones Unidas }{ }^{1}, \text { OPS }^{44} \text {, Kalipeni y } \\
\text { Oppong }^{34}, \text { Paho }^{52}\end{array}$ \\
\hline
\end{tabular}

OMS: World Health Organization; IASC: Inter-Agency Standing Committee; PAHO: Pan American Health Organization; OPS: Pan American Health Organization

Other factors have also been identified on the challenges for the HS:

- The amount of displaced populations: individual or family (drop by drop) or massive (more than 10 families or 50 persons) $)^{21,53}$.

- The existing resources in the receiving area and previous planning. According to the WHO, the political and security conditions of a country allow predicting possible displacements, planning activities and resources, and creating protocols for when the situation occurs ${ }^{5,54}$.

- The displacement stage: initial (addressed as a health emergency) or in the final settlement stage ${ }^{4,21,51,55}$.

- Population type: minority ethnic groups or population similar to the receiving area ${ }^{37}$. Most displaced populations in the Latin America are ethnic minorities (indigenous and Afro-descendants) ${ }^{14,56-58}$.

- The age groups of the displaced population and their health status ${ }^{1,5,27,28,47,59-67}$, with emphasis on childhood, adolescence, adult women, minority ethnic groups, the lesbian, gay, bisexual, transsexual, and intersexual population (LGBTI) population, and persons with disabilities or chronic or infectious disease requiring long-term treatment, such as TB and AIDS (Box 2).

Since most displaced populations have a low educational level ${ }^{19,62}$, they require information on health, rights, and services, to improve their use, especially on SRH (prevention and detection of cervical and breast cancer, sexually transmitted infections/HIV, and family planning $)^{55}$. 
Box 2. Priorities of care according to age group in displaced population, found in the 1995-2016 literature review on displaced population and health services.

\begin{tabular}{|c|c|c|}
\hline Age group & Priorities & Authors \\
\hline Childhood & $\begin{array}{l}\text { Because of the vulnerability of this group to food } \\
\text { shortages, health conditions, changes in residence, } \\
\text { and post-traumatic stress disorder (PTSD) and its } \\
\text { consequences, it is recommended to emphasize } \\
\text { on: continuity of maternal breastfeeding, } \\
\text { vaccination, nutrition, detection and addressing } \\
\text { of mental health problems with family and school } \\
\text { interventions, and friendly health services }\end{array}$ & $\begin{array}{l}\text { James et al. }{ }^{59} \text {, Kataoka et al. }{ }^{60} \text {, } \text { Patten }^{61} \text {, } \\
\text { Ruiz Rodriguez et al. }{ }^{28} \text {, Thomas and } \\
\text { Thomas }^{5} \text {, Fox et al. }{ }^{47} \text {, Gómez Builes } \\
\text { et al. }{ }^{56} \text {, Ballesteros-P et al. }{ }^{27} \text {, Baquero } \\
{\text { Latorre et al. }{ }^{62} \text {, Cámara de Diputados }}^{91}\end{array}$ \\
\hline Adolescence & $\begin{array}{l}\text { Prevention of sexual or economic exploitation } \\
\text { or violence, STI/HIV, pregnancy, addictions, } \\
\text { and PTSD }\end{array}$ & $\begin{array}{l}\text { Thomas and Thomas }{ }^{5} \text {, Salama and } \\
\text { Dondero }{ }^{63} \text {, Zea et al. }{ }^{64} \text {, Yearwood } \\
\text { et al. }{ }^{65} \text {, Mogollón Pérez e Vásquez } \\
\text { Navarrete }^{66} \text {, Cámara de Diputados }{ }^{91}\end{array}$ \\
\hline Adult women & $\begin{array}{l}\text { Psychosocial care of pregnant women and } \\
\text { mothers head of the family }\end{array}$ & $\begin{array}{l}\text { Mogollón Pérez and Vásquez } \\
\text { Navarrete }^{66}, \text { Organización de las } \\
\text { Naciones Unidas }{ }^{1}, \text { Ballesteros-P et al. }{ }^{27} \text {, } \\
\text { Roberston et al. }{ }^{68}\end{array}$ \\
\hline
\end{tabular}

PTSD: post-traumatic stress syndrome; STI/HIV: sexually transmitted infections/HIV

\section{Health Needs of the Displaced Population}

Given the lack of specific information about the challenges to HS, they can be deduced from the health information of the displaced population, which is abundant. Although the conditions of forced migration by violence in other continents are different because of their magnitude and socio-political context, there are common characteristics in displaced populations: most are poor, women, with low education level, with traumatic experiences and stress, placed in areas with poor health conditions, with few belongings, and often without identity documents ${ }^{5}$.

Most references have identified mental health problems ${ }^{42,44,50,60,68-72}$ from stress and the accompanying trauma of displacement, often preceded by murders, threats, violations, and losses. To this, we can add the stress in the receiving area, from unemployment, discrimination, and loss of networks. The most common problems were depression and post-traumatic stress syndrome (PTSD), whose magnitude depends on personal factors and the environment $t^{5,57,71-73}$.

The second most mentioned subject was the SRH needs of women, especially teenagers, because of the risk of sexual abuse and exploitation both at the receiving place and within the displaced group itself ${ }^{74,75}$. This involves efforts to identify and prevent unwanted pregnancy, STI/HIV, and unsafe abortion and to ensure the availability of contraceptives, including emergency contraceptives, and antiretrovirals $\mathrm{s}^{1,5,73,75,76}$.

Other groups mentioned were older adults ${ }^{53}$ and persons with disabilities ${ }^{1,53}$. The LGBTI population was considered important because of the discrimination they may be subject to, even in the HS, and those with STI/HIV treatments to ensure continuity ${ }^{1,77}$. Hence the importance of having an epidemiological surveillance system ${ }^{63}$ that ensures timely diagnosis and continuity of treatment, as well as the diagnosis of available resources. We found some articles on specific subjects: increased canine rabies in displaced areas $^{78}$, oral health ${ }^{79,80}$, and occupational health ${ }^{26,81}$.

\section{Components of the HS}

The PAHO comments that a massive internal displacement produces an increased magnitude and distribution of the burden of the disease and, therefore, increases the volume and composition of the demand for services ${ }^{36}$. Most documents mentioned one or more of the HS components:

- Infrastructure and equipment: in addition to the resources for emergency humanitarian care, health care actions are contemplated as part of the integral care of the victims. 
They can be individual (prosthesis, physical and mental rehabilitation) or collective (provision of equipment and inputs, construction of health centers) ${ }^{82,83}$. Massive displacement can cause shortages of care resources in the absence of appropriate preparation for these situations ${ }^{30}$.

- Human resources (HR). The health staff needs to be trained on the care of displaced populations $s^{5.54}$, as well as state and city authorities. Adequate remuneration and emotional restraint are important in the initial stages of emergency, followed by security measures ${ }^{26,36,82}$. International agencies have designed manuals for emergency care and for mental health problems in this population ${ }^{36,44,72,84-86}$.

- Reinforcement of services: in particular $\mathrm{SRH}^{5,75,76}$ and mental health ${ }^{42,55}$. In Colombia, the Integral Care System for Population Displaced by Violence details the HS required. The services range from prevention and emergency care up to psychosocial relocation and rehabilitation ${ }^{48}$.

- The financing of health care for displaced populations was a scarce subject in the documents. There was a consensus that financial resources are scarce or late ${ }^{30}$ and national budget actions are needed so that the local population is not negatively affected ${ }^{12}$. Other texts mentioned funding sources ${ }^{29,87}$, payment mechanisms ${ }^{29,86,88}$, or the budget allocated for the reparation of victims ${ }^{35}$. However, no article has done a detailed study of health costs derived from displacement ${ }^{89}$. Given that displaced families are poor and should also abandon their sources of income, their ability to pay is minimal, even for transportation to the health unit ${ }^{53}$. The WHO highlights the persistent scarcity of resources for mental health care, a priority service for displaced populations ${ }^{85}$.

- Other components: different subjects have been addressed, such as intersectoriality, participation, and empowerment of the displaced population ${ }^{4,29,55,82}$, the role of nongovernmental organizations ${ }^{14,21,55}$, and the role of the academy $y^{28,35,41,62,80}$ both in care and in research.

\section{The Situation in Mexico}

Despite underreporting, 281,418 persons are known to be victims of internal displacement forced by violence, mainly in the Northern states and Guerrero, caused by organized crime $^{21}$ or religious problems. In general, the subject of displaced populations has been little studied and recognized, with no specific policies or legal framework in the field of health services ${ }^{23,53}$. An exception is Chiapas, where a law was passed to protect the rights of this population ${ }^{90}$. There are state legislations in Guerrero and Sinaloa ${ }^{14}$. The Federal Project for the Care of Displaced Indigenous People does not include health aspects, but it recognizes both the existence of an indigenous population displaced by some type of violence and the lack of specific legislation that recognizes and characterizes it ${ }^{58}$. Other state responses include emergency response and intersectoral committees (Guerrero) and employment programs (Sinaloa, Durango). The General Victim Law of $2013^{91}$, which allowed the registration of victims, does not operate in all states; its Executive Committee does not have enough budget or service protocols or state laws for the Prevention and Care of Internal Displacement, which includes the right to medical services ${ }^{14,21,90}$. The initiative of a Federal Law for Internally Displaced People, introduced to the Chamber of Deputies in 1998, was dismissed.

The Arana document on the situation in Chiapas highlights the lack of information to identify population groups and needs for their care, and it reinforces the connection between forced displacement and health ${ }^{23}$ :

"Forced displacement is one of the clearest examples of the interdependence between rights. Violation of civil rights of security and free residence from the use of physical and/or psychological force to expel a population unleashes an unpredictable series of negative consequences that hinder the exercise of the right to health and a long list of economic, social, and cultural rights." (p.79) 


\section{DISCUSSION}

Forced displacement is an issue that violates human rights. It produces highly frail individuals and groups from a profound deterioration in the quality of life and health and the lack of care by the Government against the right to health ${ }^{56}$. We found no specific studies that have aimed to analyze the impact of forced displacement on HS, which is probably more related to the redistribution of the same resources. The mental health and rehabilitation aspects, traditionally and precariously cared for in the health system, are still pending.

While most documents refer to migration by violence from one country to another, rather than internal migration, the diagnosis of the needs of the migrant population generally allows the deduction of the impact and challenges for the HS. In Latin America, most of the literature refers to Colombia, where the magnitude of the problem is enormous and has been assumed as a national priority. This has resulted in a reliable system of registration, strategies, and policies specific to this population and a large number of research and interventions have been carried out by the academia, cities, NGO, and international organizations. For this reason, the Colombian experience is recommended as an example for Mexico ${ }^{53}$. In Peru, reparations for victims include care for disabilities, full recovery of community mental health, capacity building, and HS infrastructure and training ${ }^{89}$. In Mexico, as long as the government does not recognize internal displacement by violence as a public health, human right, and national security violation, actions to mitigate it will have little political and financial viability. States and cities and the displaced population itself must face the resources and health problems from the displacement.

Based on the results, the main challenges for the Mexican health system would be $^{23-25,45,49,50,62,69,73,75,83,92}$ :

1. Integral, intersectoral, and participatory approach, which requires multidisciplinary teams that are sensitized and trained ${ }^{4}$ and political will at all levels.

2. Ensuring of the geographical, cultural, economic, and functional accessibility to the HS, taking into account the psychosocial particularities of the displaced population, such as psychosocial trauma (fear, pain, uncertainty) and lack of resources, as well as the limitations of the benefit plan of the Popular Insurance.

3. Presence of a reliable information and registration system for the displaced population and its characteristics, which allows prioritizing activities and groups, with the participation of community leaders that facilitate the approach of the population and the flow of information.

4. Analysis and adaptation of successful experiences of other Latin American countries for the care and reparation of the population displaced by violence.

5. Full addressing of the problems of different groups, especially women, and within them, young women, who, in addition to the specific SRH needs, face the risk of sexual violence and domestic violence because of the gender. In addition, many become the head of a family, thus requiring great psychosocial support.

6. Given the high vulnerability of the displaced population to mental health problems, this problem must be studied and addressed in order to avoid negative individual, family, and social consequences.

To address these challenges adequately, the Mexican government must recognize the existence of displaced populations to plan resources and design policies ${ }^{23,53}$; it must activate a comprehensive humanitarian strategy to promote their rights and design a specific legal framework for the protection of internally displaced persons, including the protection of their health ${ }^{35,93}$. 
Forced displacement accumulates vulnerabilities from losses: political and social rights, family and social networks, and adverse social and health conditions that are present in the receiving areas. These situations increase the burden of the disease and pressure the demand for health services that respond to health needs, particularly mental health needs. The WHO warns about the consequences of conflicts for public health and health systems which may have a decreased ability to respond adequately to new demands ${ }^{94}$. The accumulation of vulnerabilities of displaced populations is a challenge for health systems regarding the implementation of policies for more sensitive services. In particular, this aspect becomes relevant in care models that have an explicit homogeneous benefit plan that affects a series of psychosocial health problems, which are excluded from the care. For example, mental health problems have not been adequately addressed in Colombia because the mental health services included in the benefit plan are not enough to meet the perceived need ${ }^{49}$. Managed care models have also shown that they are not sensitive to the care of mental health problems ${ }^{95}$.

Forced displacement is a determinant of social and health inequities. It is closely related to structural factors, such as economic distribution, land, human rights, and intermediate factors such as socioeconomic status and health system. This aspect exposes another challenge for health systems regarding the inter- and trans-sectoral work that favors the social mobilization of players other than those in the health sector to enhance interventions in health services. Health systems should be centered on more comprehensive strategies, such as Primary Health Care and Health Promotion, and focused on Social Determinants, which have close relations.

Knowledge about the health problems and needs of the displaced population and its impact on the HS can be used to define programs, strategies, and policies that address this growing problem in Mexico. National and international experiences are an important reference for the country. Colombia has a broad trajectory in this area and has a National System of Integral Care for displaced populations and specific strategies of health care. Strategies include the training of health managers and mobile brigades, in addition to those designed and evaluated with the follow-up of the Pan American Health Organization ${ }^{33}$, with funding defined for each sector, a national registry of victims, and promotion of community participation in decisionmaking. This could be used by the Mexican Government ${ }^{29}$.

Despite the limitation of the scarcity of specific information on the subject, as shown in the Table, the analysis of the data found allows us to conclude that the Health System must respond to the needs of the different displaced groups and to the multiethnic and multicultural nature of Mexico with integral focus and rights, and with an anticipatory nature to avoid improvisation. The lack of political will to accept and see the internal displacement by violence and its importance as a humanitarian and public health problem is an obstacle to assist adequately and timely the population displaced by violence in Mexico. It is the responsibility of the three levels of the government to care for displaced populations and the redeployment of resources between sending and receiving areas and the awareness and training of health personnel for work in social and health emergency situations. Given the vulnerability characteristics of displaced populations, Mexico needs to develop a registry and a diagnosis of the physical and emotional health problems of this population to mitigate the suffering and the consequences in the short and long term. The component of social and community participation, which is present in primary health care and health promotion, is a fundamental element to ensure the right to health of the displaced population. Quantitative and qualitative research on the effect of internal displacement forced by violence on the HS in Mexico is needed to provide information for the planning of the strategies and resources needed for the health care of the growing displaced populations.

\section{REFERENCES}

1. Organización de las Naciones Unidas, Comisión de Derechos Humanos. Principios rectores de los desplazamientos internos. Ginebra, Suiza: ACNUR; 1998. (E/CN.4/1998/53/Add.2). Available from: https://www.icrc.org/spa/resources/documents/misc/5tdmhb.htm 
2. Organización Mundial de la Salud, Consejo Ejecutivo 122. Salud de los migrantes: informe de la Secretaría. Ginebra: OMS; 2008 [cited 2016 Jul 7]. Available from: http://apps.who.int/iris/ bitstream/10665/26222/1/A61_12-sp.pdf

3. International Displacement Monitoring Centre. Mexico: limited response to displacement following local and regional conflicts. Ginebra: IDMC; 2009.

4. Rodríguez Neyra CL. Programa de Salud Familiar de Primer Nivel con equipo extramural para población desplazada en Neiva: Convenio HU-0002 ESE Carmen Emilia Ospina - OIM. Neiva: Organización Internacional para las Migraciones; 2004 [cited 2016 Jul 7]. Available from: https://publications.iom.int/system/files/pdf/salud_familiar-1.pdf

5. Thomas SL, Thomas SD. Displacement and health. Br Med Bull. 2004;69(1):115-27. https://doi.org/10.1093/bmb/ldh009

6. Gamboa Delgado EM, López Barbosa N, Vera Cala LM, Prada Gómez GE. Patrón alimentario y estado nutricional en niños desplazados en Piedecuesta, Colombia. Rev Salud Publica. 2007 [cited 2016 Jul 7];9(1):129-39. Available from: http://www.scielo.org.co/pdf/rsap/v9n1/v9n1a14.pdf

7. Programa Mundial de Alimentos Colombia. Estudio de caso de las necesidades alimentarias de la población desplazada de Colombia. Bogotá; 2001 [cited 2016 Jul 7]. Available from: https://reliefweb.int/ report/colombia/estudio-de-caso-de-las-necesidades-alimentarias-de-la-poblaci\%C3\%B3n-desplazada-de

8. Martínez-García JS. Las clases sociales y el capital en Pierre Bourdieu un intento de aclaración. Salamanca: Universidad de Salamanca; s.d. (Serie Análisis, Documento P/10 98-PB94/1382).

9. Mogollón Pérez AS, Vázquez Navarrete ML, García Gil MM. Necesidades en salud de la población desplazada por conflicto armado en Bogotá. Rev Esp Salud Publica. 2003 [cited 2016 Jul 7];77(2):257-66. Available from: http://scielo.isciii.es/pdf/resp/v77n2/original7.pdf

10. Vásquez Salazar E, Ochoa Marín S, Duarte MB. Respuesta al riesgo de infecciones de transmisión sexual en hombres en situación de desplazamiento forzado. Rev Salud Publica. 2012 [cited 2016 Jul 7];14(6):989-1000. Available from: http://www.scielo.org.co/pdf/rsap/v14n6/v14n6a09.pdf

11. García Durán M. Los desplazados por la violencia en Colombia. Con su dolor sin rumbo. Univ Humanist. 1999 [cited 2016 Jul 7];47:15-31. Available from: http://revistas.javeriana.edu.co/ index.php/univhumanistica/article/view/9584

12. Bernal Pulido LG. Atención en salud de familias desplazadas por la violencia: reflexiones desde la experiencia docente-asistencial. Univ Med. 2009 [cited 2016 Apr 17];50(2):172-83. Available from: http://www.redalyc.org/articulo.oa?id=231018809004

13. Barajas Sandoval LC. Salud y derechos en el contexto de la ley, no de la vida. Nomadas (Col). 2013 [cited 2016 Jul 7];(38):254-66. Available from: http://www.redalyc.org/articulo.oa?id=105127475017

14. Comisión Mexicana para la Defensa y Promoción de los Derechos Humanos. Desplazamiento interno forzado en México. México (DF): CMDPDH; 2014 [cited 2016 Jul 7]. Available from: http://www.cmdpdh.org/publicaciones-pdf/cmdpdh-desplazamiento-web.pdf

15. Instituto Nacional de Estadística y Geografía. Censo de Población y Vivienda 2010: migración interna (estatal): población emigrante por entidad federativa según lugar de nacimiento, 2000 y 2010. México (DF); INEGl; 2010 [cited 2016 Apr 21]. Available from: http://www3.inegi.org.mx/ sistemas/sisept/Default.aspx?t=mdemo134\&s=est\&c=23628

16. Chávez AM. La migración interna en México. En: Valdés LM, editor. Derechos de los mexicanos: introducción al derecho demográfico. México (DF): Instituto de Investigaciones JurídicasUNAM; 2009. p.267-81.

17. Instituto Nacional de Estadística y Geografía. Consejo Nacional de Población. Encuesta Nacional de la Dinámica Demográfica ENADID 2014: principales resultados. México (DF): INEGl; 2014 [cited 2016 Jul 7]. Available from: http://www.inegi.org.mx/est/contenidos/ proyectos/encuestas/hogares/especiales/enadid/enadid2014/doc/resultados_enadid14.pdf

18. Instituto Nacional de Estadística y Geografía. Encuesta Nacional de Victimización y Percepción sobre Seguridad Pública (ENVIPE) 2014. México (DF): INEGl; 2014. [cited 2016 Jul 7]. Available from: http:// www.inegi.org.mx/est/contenidos/proyectos/encuestas/hogares/regulares/envipe/envipe2014/default.aspx

19. Chávez-Juárez FW, Wanner P. Determinants of internal migration in Mexico at an aggregated and a disaggregated level. Rochester: SSRN; 2012 [cited 2016 Jul 16]. (SSRN Working Paper Series). Available from: http://papers.ssrn.com/sol3/papers.cfm?abstract_id=1978806

20. Leyva Flores R, Quintino F, Caballero M, Infante C. Migración internacional y VIH/SIDA en México. En: Leyte P, Giorguli S E, coordinadoras. El estado de la migración: las políticas públicas ante los retos de la migración mexicana a Estados Unidos. México (DF): Consejo Nacional de Población; 2009. p.249-64. 
21. Internal Displacement Monitoring Centre. Global overview 2015: people internally displaced by conflict and violence. Geneva: IDMC; 2015 [cited 2016 Jul 7]. Available from: http://www. internal-displacement.org/library/publications/2015/global-overview-2015-people-internallydisplaced-by-conflict-and-violence

22. Centro Internacional para los Derechos Humanos de los Migrantes. Desplazamiento forzado y necesidades de protección generados por nuevas formas de violencia y criminalidad en Centroamérica. San José de Costa Rica: CIDEHUM/ACNUR; 2012.

23. Arana Cedeño M, Riego MT, Swanson SS, Barreda Ruiz E. Estudios sobre los desplazados por el conflicto armado en Chiapas. México (DF): Programa Conjunto por una Cultura de Paz; 2012 [cited 2016 Jul 7]. Available from: https://www.sdgfund.org/sites/default/files/CPPB_\%20 ESTUDIO_\%20Mexico_Estudio\%20sobre\%20los\%20desplazados.pdf

24. Reynolds S. Las víctimas ocultas de México. Refugees Int. 2 jul 2014 [cited 2016 Jul 7]. Available from: http://www.acnur.org/t3/uploads/media/2883_COI_Mexico_las_victimas_ ocultas.pdf?view $=1$

25. Siriwardhana C, Stewart R. Forced migration and mental health: prolonged internal displacement, return migration and resilience. Int Health. 2013;5(1):19-23. https://doi.org/10.1093/inthealth/ihs014

26. Siem H. Migration and health: the international perspective. Praxis (Bern 1994). 1997;86(19):788-93.

27. Ballesteros-P MP, Gaviria-L MB, Martínez-B SE. Caracterización del acceso a los servicios de salud en población infantil desplazada y receptora en asentamientos marginales en seis ciudades de Colombia, 2002-2003. Rev Fac Nac Salud Publica. 2006 [cited 2016 Jul 7];24(1):7-17. Available from: http://www.redalyc.org/articulo.oa?id=12024102

28. Ruiz Rodriguez M, López Moreno S, Ávila Burgos L, Acosta Ramirez N. Utilización de servicios médicos por una población desplazada en Bucaramanga, Colombia. Rev Salud Publica. 2006 [cited 2016 Jul 7];8(3):197-206. Available from: http://www.scielo.org.co/pdf/rsap/v8n3/v8n3a05.pdf

29. Balladelli PP, Rodriguez Neira CL, Hernández Torres J. Ruta y Siga: acceso de la población desplazada a los servicios de salud. Bogotá: Organización Panamericana de la Salud; 2009 [cited 2016 Jul 7]. (Buenas Prácticas en Salud Pública en Colombia). Available from: http://www. paho.org/col/index.php?option=com_docman\&view=download\&category_slug=publicacionesops-oms-colombia\&alias=1296-ruta-siga-acceso-psd\&ltemid=688

30. Mogollón Pérez AS, Vázquez ML. Factores que inciden en el acceso de la población desplazada a las instituciones prestadoras de servicios de salud en Colombia. Cad Saude Publica. 2008;24(4):745-54. https://doi.org/10.1590/S0102-311X2008000400004

31. Vidal López RC, coordinador, Atehortúa Arredondo Cl, Salcedo J. Efectos del desplazamiento interno en las comunidades de las zonas de recepción: estudio de caso en Bogotá, DC Colombia, en las localidades de Suba y Ciudad Bolívar. Bogotá: Proyecto del Instituto Brookings-London School of Economics sobre el Desplazamiento Interno; 2011 [cited 2016 Jul 16]. Available from: https://www. brookings.edu/wp-content/uploads/2016/06/Host-Communities-Colombia-Spanish.pdf

32. Organización Panamericana de la Salud; Escuela de Formación Administrativa en Salud. Atención en salud para la población en situación de desplazamiento. Bucaramanga (CO): OPS; 2004 [cited 2016 Jul 16]. Available from: http://www.paho.org/col/index.php?option=com_ docman\&view=download\&category_slug=publicaciones-ops-oms-colombia\&alias=21-atencionen-salud-para-la-poblacion-en-situacion-de-desplazamiento\&Itemid=688

33. Organización Panamericana de la Salud. Proyecto para mejorar las condiciones generales de vida a las familias reubicadas y desplazadas por la violencia: equipos itinerantes de atención a desplazados. Bogotá: OPS; s.d.

34. Kalipeni E, Oppong J. The refugee crisis in Africa and implications for health and disease: a political ecology approach. Soc Sci Med. 1998;46(12):1637-53. https://doi.org/10.1016/S0277-9536(97)10129-0

35. Ibáñez AM, Velásquez A. La política pública para atender a la población desplazada. ¿Cuáles deben ser las funciones de las autoridades locales? Washington (DC): La Institución BrookingsUniversidad de Berna; 2008 [cited 2016 Jul 16]. Available from: https://www.brookings.edu/wpcontent/uploads/2016/06/1203_colombia_ibanez_spa.pdf

36. Organización Panamericana de la Salud. Más de un decenio de salud para la población desplazada en Colombia 1998-2011. Bogotá: OPS; 2012.

37. Juliao-Vargas CS. Los desplazados en Bogotá y Soacha: características y protección. Rev Paz Conflictos. 2011 [cited 2016 Jul 16];4:102-20. Available from: http://revistaseug.ugr.es/index. php/revpaz/article/view/457/525 
38. Latta RE, Goodman LA. Considering the interplay of cultural context and service provision in intimate partner violence: the case of Haitian immigrant women. Violence Against Women. 2005;11(11):1441-64. https://doi.org/10.1177/1077801205280273

39. Kinzie JD. Immigrants and refugees: the psychiatric perspective. Transcult Psychiatry. 2006;43(4):577-91. https://doi.org/10.1177/1363461506070782

40. UNICEF. Migrantes y derecho a la salud: material de consulta para trabajadores/as del sistema de salud. Buenos Aires; 2012 [cited 2016 Jul 16]. Available from: http://files.unicef.org/argentina/ spanish/Cuadernillo_efectores.pdf

41. Alcaraz López GM, Ochoa Marín SC, López Torres ZA. Atención en salud a mujeres en situación de desplazamiento: una mirada desde los prestadores de servicios sociales y de salud. Index Enferm. 2012;21(3):155-9. https://doi.org/10.4321/S1132-12962012000200010

42. Comité Permanente entre Organismos. Guía del IASC sobre Salud Mental y Apoyo Psicosocial en Situaciones de Emergencia. Ginebra: IASC; 2007 [cited 2016 Jul 16]. Capítulo 3. Listas de acciones que constituyen la respuesta mínima: servicios de salud. p.130-60. Available from: http://www.who.int/hac/techguidance/iascguidelinesspanish.pdf

43. Hernández Bello A, Gutiérrez Bonilla ML. Vulnerabilidad y exclusión: condiciones de vida, situación de salud y acceso a servicios de salud de la población desplazada por la violencia asentada en Bogotá-Colombia, 2005. Rev Gerenc Polit Salud. 2008 [cited 2016 Jul 16];7(14):145-76. Available from: http://www.scielo.org.co/pdf/rgps/v7n14/v7n14a09.pdf

44. Haghebaert GVKA, Zacarelli Davoli M. La salud mental y el desplazamiento forzado. En: Organiización Panamericana de la Salud. Guía práctica de salud mental en desastres. Washington (DC): OPS; 2006 [cited 2016 Jul 16]. Capítulo 8, p.153-67. Available from: http:// www1.paho.org/hq/dmdocuments/2008/GuiaPracticadeSaludMental.pdf?ua=1

45. Schuster S, Schwendke A. [Violence against women in the context of migration]. Ther Umsch. 2005;62(4):239-43. German. https://doi.org/10.1024/0040-5930.62.4.239

46. Silva JC. Población desplazada internamente en Cartagena, Colombia: una intervención de la Organización Panamericana de la Salud. Bogotá: OPS; 2001.

47. Fox PG, Rossetti J, Burns KR, Popovich J. Southeast Asian refugee children: a school-based mental health intervention. Int J Psychiatr Nurs Res. 2005;11(1):1227-36.

48. Ministerio de Protección Social. Circular Externa Nº64. Cumplimiento de la orden contenida en el ordinal octavo de la parte resolutiva de la sentencia T-025 de 2004 emitida por la Corte Constitucional, que prohíbe incorporar la interposición de la acción de tutela como requisito para acceder a los beneficios otorgados a la población desplazada; 2005. Available from: https:// www.minsalud.gov.co/sites/rid/Lists/BibliotecaDigital/RIDE/DE/DIJ/Circular_Externa_064_ de_2005.pdf

49. Ruiz Rodríguez M, Wirtz VJ, Idrovo AJ, Angulo ML. Access to medicines among internally displaced and non-displaced people in urban areas in Colombia. Cad Saude Publica. 2012;28(12):2245-56. https://doi.org/10.1590/S0102-311X2012001400004

50. Cáceres DC, Izquierdo VF, Mantilla L, Jara J, Velandia M. Perfil epidemiológico de la población desplazada por el conflicto armado interno país en un barrio de Cartagena, Colombia, 2000. Biomedica. 2002;22 Supl 2:25-44. https://doi.org/10.7705/biomedica.v22iSupp2.1191

51. Moreno-G GA, Monsalve-B JC, Tabima-G D, Escobar-M JI. Apreciaciones de la población en condición de desplazamiento forzado sobre los servicios de salud en algunos municipios de Colombia. Rev Fac Nac Salud Publica. 2009 [cited 2016 Jul 16];27(2):131-41. Available from: http://www.scielo.org.co/pdf/rfnsp/v27n2/v27n2a04.pdf

52. Pan American Health Organization. Health, human security and well-being. Washington (DC): PAHO; 2010 [cited 2016 Jul 16]. Available from: http://iris.paho.org/xmlui/bitstream/ handle/123456789/31132/CD50-17-e.pdf?sequence=1\&isAllowed=y

53. Aquino Cruz T, Sánchez García D. Hacia la construcción de políticas públicas en materia de atención de grupos discriminados a causa del desplazamiento forzado de su lugar de origen. México (DF): CONAPRED; 2008 [cited 2016 Jul 16]. Available from: http://www.conapred.org. mx/documentos_cedoc/E07-2008_FINAL.pdf

54. Organización Mundial de la Salud. El informe sobre la salud en el mundo 2006: colaboremos por la salud. Ginebra: OMS; 2006 [cited 2016 Jul 16]. Available from: http://www.who.int/whr/2006/es/

55. Gomes C, Murad R. Encuesta sobre zonas marginadas, salud sexual y reproductiva, desplazamiento y pobreza 2000-2011. Bogotá: Profamilia; 2011. 
56. Gómez Builes GM, Astaiza Arias GM, Minayo MCS. Las migraciones forzadas por la violencia: el caso de Colombia. Cienc Saude Coletiva. 2008;13(5):1649-60. https://doi.org/10.1590/S1413-81232008000500028

57. Moya Medina J, López-Moreno S. Cambios en la percepción de salud en población desplazada por la guerra, Ayacucho, Perú: 1980-2004. Cienc Saude Coletiva. 2011;16(3):1699-708. https://doi.org/10.1590/S1413-81232011000300007

58. Comisión Nacional para el Desarrollo de los Pueblos Indígenas (MX). Lineamientos específicos del Proyecto para la Atención a Indígenas Desplazados. Diario Oficial Fed Estad Mex. 15 jun 2006 [cited 2016 Jul 16]; Sección 1:82-6. Available from: http://www.cdi.gob.mx/programas/lineamientos/ lineamientos_especificos_del_proyecto_para_la_atencion_a_indigenas_desplazados.pdf

59. James S, Landsverk J, Slymen DJ, Leslie LK. Predictors of outpatient mental health service use: the role of foster care placement change. Ment Health Serv Res. 2004;6(3):127-41. https://doi.org/10.1023/B:MHSR.0000036487.39001.51

60. Kataoka SH, Stein BD, Jaycox LH, Wong M, Escudero P, Tu W, et al. A school-based mental health program for traumatized Latino immigrant children. J Am Acad Child Adolesc Psychiatry. 2003;42(3):311-8. https://doi.org/10.1097/00004583-200303000-00011

61. Patten T. Breastfeeding promotion: a vital emergency intervention disregarded? Afr Health. 1997;19(6):24.

62. Baquero Latorre H, Faillace M, Vanegas C, Salas S, Cordero C. Impacto biopsicosocial del desplazamiento forzado en una población menor de 12 años del Asentamiento kilómetro 7 , Barranquilla. Hospital Universidad del Norte, Hospital Niño de Jesús. Barranquilla, 2003. Salud Uninorte. 2005 [cited 2016 Jul 16];20:30-44. Available from: http://rcientificas.uninorte.edu.co/ index.php/salud/article/viewArticle/4116/5668

63. Salama P, Dondero TJ. HIV surveillance in complex emergencies. AIDS. 2001;15 Suppl 3:S4-12.

64. Zea MC, Reisen CA, Bianchi FT, Gonzales FA, Betancourt F, Aguilar M, et al. Armed conflict, homonegativity and forced internal displacement: implications for HIV among Colombian gay, bisexual and transgender individuals. Cult Health Sex. 2013;15(7):788-803. https://doi.org/h10.1080/13691058.2013.779028

65. Yearwood EL, Crawford S, Kelly M, Moreno N. Immigrant youth at risk for disorders of mood: recognizing complex dynamics. Arch Psychiatr Nurs. 2007;21(3):162-71. https://doi.org/10.1016/j.apnu.2007.02.006

66. Mogollón Pérez AS, Vázquez Navarrete ML. Opinión de las mujeres desplazadas sobre la repercusión en su salud del desplazamiento forzado. Gac Sanit. 2006;20(4):260-5. https://doi.org/10.1157/13091139

67. Pinilla Gómez E, Pérez Sierra JM. Prevalencia de diagnósticos de enfermería en escolares desplazados víctimas de la violencia social e intrafamiliar. Rev Univ Ind Santander Salud. 2009 [cited 2016 Jul 16];41(2):149-56. Available from: http://www.scielo.org.co/pdf/suis/v41n2/v41n2a06.pdf

68. Robertson CL, Halcon L, Savik K, Johnson D, Spring M, Butcher J, et al. Somali and Oromo refugee women: trauma and associated factors. J Adv Nurs. 2006;56(6):577-87. https://doi.org/10.1111/j.1365-2648.2006.04057.x

69. Vilar Peyrí E, Eibenschutz Hartman C. Migración y salud mental: un problema emergente de salud pública. Rev Gerenc Polit Salud. 2007 [cited 2016 Jul 16];6(13):11-32. Available from: http://revistas.javeriana.edu.co/index.php/gerepolsal/article/view/2689/1948

70. Díez Ruiz GP, Agudelo Suarez LM. Condiciones de salud de familias desplazados por violencia en Urabá, 1997. Rev CES Med. 1997 [cited 2016 Jul 16]. Available from: http://revistas.ces.edu. co/index.php/medicina/article/view/1060/654

71. Eisenman DP, Gelberg L, Liu H, Shapiro MF. Mental health and health-related quality of life among adult Latino primary care patients living in the United States with previous exposure to political violence. JAMA. 2003;290(5):627-34. https://doi.org/10.1001/jama.290.5.627

72. Organización Mundial de la Salud. Sanar las heridas invisibles del conflicto sirio. Bull World Health Organ. 2016;94:6-7. https://doi.org/10.2471/BLT.16.020116

73. Cohen SA. The reproductive health needs of refugees: emerging consensus attracts predictable controversy. Guttmacher Rep Public Policy. 1998 [cited 2016 Jul 16];1(5):10-2. Available from: https://www.guttmacher.org/sites/default/files/article_files/gr010510.pdf

74. Ecker N. Where there is no village: teaching about sexuality in crisis situations. SIECUS Rep. 1998;26(5):7-10.

75. Marie Stopes International. MSI develops refugee initiative. First People. 1996 Summer:2. 
76. Otsea K. Prioritizing reproductive health for refugees. Initiat Reprod Health Policy. 1999;3(1):1-3.

77. Kapp C. Health crisis worsens in Zimbabwe. Lancet. 2007;369(9578):1987-8. https://doi.org/10.1016/S0140-6736(07)60927-1

78. Cediel N, De la Hoz F, Villamil LC, Romero J, Díaz A. The epidemiology of canine rabies in Colombia. Rev Salud Publica. 2010 [cited 2016 Jul 16];12(3):368-79. Available from: http://www.scielo.org.co/pdf/rsap/v12n3/v12n3a03.pdf

79. Agudelo-S AA, Isaza-S LT, Bustamante-B DA, Martínez-O CM, Martínez-D CM. Morbilidad bucal percibida y características sociales en la población desplazada y destechada de un asentamiento del municipio de Bello (Antioquia), 2005. Rev Fac Odontol Univ Antioq. 2006 [cited 2016 Jul 16];18(1):36-46. Available from: https://aprendeenlinea.udea.edu.co/revistas/index.php/odont/ article/view/2773/2865

80. Agudelo AA, Isaza LT, Bustamante DA, Martínez CM, Martínez CM. Perfil epidemiológico bucal en un asentamiento de población desplazada y destechada (Antioquia-Colombia). Rev CES Odontol. 2008 [cited 2016 Jul 16] ;21(2):17-24. Available from: http://revistas.ces.edu.co/index. php/odontologia/article/view/293/191

81. Ardila Jaimes CP, Rodriguez Amaya RM. Condiciones de salud y laborales de la población trabajadora informal en situación de desplazamiento de Bucaramanga, Colombia. Invest Andina. 2013 [cited 2016 Jul 16];15(26):628-39. Available from: http://www.scielo.org.co/pdf/inan/v15n26/v15n26a02.pdf

82. Paredes Palma S, Correa C. ¿Cuánto se ha reparado en nuestras comunidades? Avances, percepciones y recomendaciones sobre reparaciones colectivas en el Perú (2007-2011). Cuarto Reporte. Impacto y Sostenibilidad de las reparaciones colectivas. Lima: Aprodeh; 2011 [cited 2016 Jul 16]. Available from: https://www.ictj.org/sites/default/files/ICTJ-Peru-Reparaciones2011-Espa\%C3\%B1ol.pdf

83. Correa C. Reparaciones en Perú: el largo camino entre las recomendaciones y la implementación. Lima: Centro Internacional para la Justicia Transicional; 2013 [cited 2016 Jul 16]. Available from: https://www.ictj.org/sites/default/files/ICTJ-Report-Peru-ReparationsSpanish-2013.pdf

84. Rodríguez J, Zaccarelli Davoli M, Pérez R, editores. Guía práctica de salud mental en situaciones de desastres. Washington (DC): OPS; 2006. (Manuales y Guías sobre Desastres, 7).

85. Organización Mundial de la Salud. El contexto de la salud mental: guías sobre servicios y políticas de salud mental. Ginebra: OMS; 2003.

86. Betancourt C, Castro JV. Financiamiento y fiscalidad de la política de atención y restablecimiento de la población desplazada en Colombia. Bogotá: CODHES; 2008.

87. Ministerio de la Protección Social (CO). Decreto № 4877 de 20 de diciembre de 2007. Modifica parcialmente el Decreto 2131 de 2003 y se dictan otras disposiciones. Diario Oficial. 20 dic 2007 [cited 2016 Jul 16]. Available from: http://www.avancejuridico.com/actualidad/ documentosoficiales/2007/46848/d4877007.html

88. Ministerio de Trabajo y Seguridad Social (CO). Circular Número 000042 de 2002. Fuentes de financiamiento de la atención en salud a la población desplazada. Diario Oficial. 28 nov 2002 [cited 2016 Jul 16]. Available from: https://www.minsalud.gov.co/Normatividad_Nuevo/ CIRCULAR\%20042\%20DE\%202002.pdf

89. Shack Yalta N. Avanzando hacia la cuantificación del gasto público de las entidades del gobierno nacional en materia de reparaciones en el marco de las recomendaciones del informe final de la Comisión de la Verdad y Reconciliación: primer informe de avance. Lima: Agencia Peruana de Cooperación Internacional; 2006 [cited 2016 Jul 16]. Available from: https://www. cepal.org/ilpes/noticias/paginas/0/36340/shack2006.pdf

90. Estado de Chiapas (MX), Secretaría General de Gobierno. Ley para la prevención y atención del desplazamiento interno en el Estado de Chiapas. Decreto № 158. Periódico Oficial. 22 feb 2012 [cited 2016 Jul 16]. Available from: http://forodfi.cndh.org.mx/Content/doc/Normativo/ Ley-DPI-Chiapas.pdf

91. Cámara de Diputados del H. Congreso de la Unión. Ley general de Víctimas. México. 9 jan 2013. Nueva Ley publicada en el Diario Oficial de la Federación el 9 de enero de 2013. Available from: http://www.pgr.gob.mx/Fiscalias/feadle/Documents/LEY\%20GENERAL\%20 DE\%20V\%C3\%8DCTIMAS.pdf

92. Prieto Rodríguez A. Salud mental: situación y tendencias. Rev Salud Publica. 2002 [cited 2016 Jul 16];4(1):74-88. Available from: http://www.scielo.org.co/pdf/rsap/v4n1/v4n1a05.pdf 
93. Arriola Gordillo M. Iniciativa con proyecto de decreto por el que se reformas y adicionan diversas disposiciones de la ley de la comisión nacional de los derechos humanos. México (DF): Senado de la República; 2014 [cited 2016 Jul 16]. Available from: http://sil.gobernacion.gob.mx/ Archivos/Documentos/2014/03/asun_3081717_20140313_1394723951.pdf

94. Organización Mundial de la Salud. Informe sobre la salud en el mundo 2007: un porvenir más seguro. Protección de la salud pública mundial en el siglo XXI. Ginebra: OMS; 2007 [cited 2016 Jul 16]. Available from: http://www.who.int/whr/2007/07_report_es.pdf?ua=1

95. Galambos C, Rocha C, McCarter AK, Chansuthus D. Managed care and mental health: personal realities. J Health Soc Policy. 2004;20(1):1-22. https://doi.org/10.1300/J045v20n01_01

Authors' Contribution: Design, planning, analysis, interpretation, and writing of the article: MBDG. Interpretation and writing of the article: SMCH. Interpretation and critical review of the article: MRR. Critical review of the article: AA. Bibliographic search and information organization:JDG. All authors have approved the final version of the study and assume public responsibility for its content.

Conflict of Interest: The authors declare no conflict of interest. 